\title{
A Letter to the Editor on "Anatomical Planes in Rectal Cancer Surgery". The Surgical Plans Provided with a Perineal Ischioanal Fossa Access, Used for Transsphincteric Rectal Resection Techniques, Should be Considered Especially in Lower Rectal Cancer Surgery
}

\author{
Transsfinkterik Rektal Rezeksiyon Teknikleri için Kullanılan, Perineal \\ Iskioanal Fossa Erişimi ile Sağlanan Cerrahi Planlar, Özellikle Alt Rektal \\ Kanser Cerrahisinde Göz Önünde Bulundurulmalıdır
}

\author{
(1) Ali Naki Yücesoy \\ Yeni Yüzyıl University Faculty of Medicine, Department of General Surgery, İstanbul, Turkey
}

Keywords: External anal sphincteric musculature, ischioanal fossa, pudendal nerve, transsphincteric rectal resection

Anahtar Kelimeler: Dış anal sfinkter kası, iskioanal fossa, pudendal sinir, transsfinkterik rektum rezeksiyonu

\section{Dear Editor,}

I read the article entitled "Anatomical Planes in Rectal Cancer Surgery", which has spectacular and educational values related to the anatomical features of the abdominopelvic cavity in rectal cancer surgery written by Açar H.A. and Kuzu M.A. in your journal. ${ }^{1}$ I would like to make some additions related to the anatomical features and anatomical planes of the rectum provided with perineal ischioanal fossa access. The rectum passes through three main anatomical cavities throughout its journey through the body: the abdominal, pelvic, and ischioanal cavities, respectively. A significant portion of the lower rectum passes through the ischioanal fossa as a part of the surgical anal canal, and fuses with the anatomical anal canal. Although abdomipelvic rectal anatomy and surgical plans are always considered in rectal cancer surgery, it is noteworthy that ischioanal surgical plans, which should be considered especially in transsphincteric rectal resection techniques for lower rectal cancer surgery, are ignored. One of the most important reasons for this condition is that the intersphincteric resection technique is the most commonly used surgical technique in lower rectal cancer surgery and the ishcioanal fossa access cannot be achieved with the intersphincteric technique (ISR). IRS techniques are performed by using perabdominal and peranal approaches. ${ }^{1,2}$ Transanal total mesorectal excision is also performed in the intersphincteric dissection plane. ${ }^{3}$ There is no doubt that the transsphincteric rectal resection techniques (TSR) could not get their deserved place in rectal cancer surgery, and should be taken into account as alternative surgical methods for lower rectal cancer. ${ }^{4,5,6,7}$ Extrasphincteric rectal dissection, transsphincteric rectal resection and proximal segmental external sphincteric excision are surgical procedures 
performed in TSR. Unlike ISR, the main reason for the anatomical and surgical differences in TSR is the use of ischioanal approaches in addition to abdominal access.

The ischioanal fossa has a inverted manner truncated prism shape between the levator ani muscle and perineum, filled with lipmatous tissue. It is covered with the obtrator fascia, and does not contain mesorectal tissue. Ischianal fossa hosts to the external anal sphincteric musculature, including the distal two-third part of the lower rectum, and this structure is named as the surgical anal canal. In this manner, the surgical anal canal is formed by two intertwined cylindrical muscular tubes, and the intersphincteric dissection plan is a potential space between both muscular tubes. ${ }^{8}$

Another important anatomical structure in the ischioanal fossa is the pudendal nerve. The pudendal nerves originate from the sacral 2,3, and 4 roots, advance through the posterior wall of the ischianal fossa as pudendal neurovascular bundles after exiting from the Alcock's canal, and give their branches to the external anal sphincteric musculature following a hook formation at its base (Figure 1). Besides the abdominopelvic anatomical features and

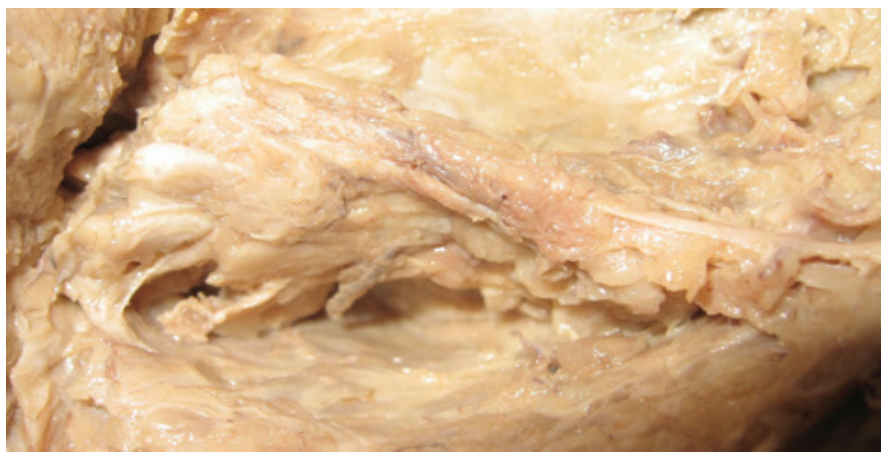

Figure 1. Posterior ischioanal cadaveric view showing the pudendal neurovascular branches of the external anal sphincteric musculature surgical plans, the ischioanal fossa should be taken into consideration, especially in lower rectal cancer, due to the elements it contains.

Informed Consent: Since the photograph used in the article belongs to the cadaver, patient approval information was not required.

Financial Disclosure: The author declared that this study received no financial support.

\section{References}

1. Schiessel R, Karner-Hanusch J, Herbst F,Teleky B,Wunderlich M Intersphincteric resection for low rectal tumours. Br J Surg. 1994;81:13761378.

2. Teramoto T,Watanabe M, Kitajima M. Per Anum intersphincteric rectal dissection with direct coloanal anastomosis for lower rectal cancer. The ultimate sphincter-preserving operation. Dis Colon Rectum 1997;40:4347.

3. Sylla P, Rattner DW, Delgado S, Lacy AM. NOTES transanal rectal cancer resection using transanal endoscopic microsurgery and laparoscopic assistance. Surg Endosc 2010;24:1205-1210.

4. Mason AY. Trans-sphincteric exposure of the rectum. Ann R Coll Surg Eng 1972;51:320-33.

5. Pena A, Hong A. The posterior sagittal trans-sphincteric and trans-rectal approaches. Tech Coloproctol.2003 ; 7(1) : 35-44.

6. Williams NS, Murphy J, Knowles CH. Anterior perineal plan for ultra-low anterior resection of the rectum the APPEAR technique) : a prospective clinical trial of a new procedure. Ann Surg. $2008 ; 247$ : 750-758.

7. Yücesoy AN. Anatomical, surgical and clinical considerations related with operative procedures performed in combined abdominal and perineal approaches for the treatment of lower rectal cancer. J Coloproctol 2018;38(1):82-89.

8. Moore KL, Dalley AF. Clinically Oriented Anatomy. LippiNCott@ WilliamsWilkins 1992; 3rd ed. 